\section{Is Spontaneous Spinal Epidural Hematoma in Elderly Patients an Emergency Surgical Case?}

\author{
Yașlı Hastalardaki Spontan Spinal \\ Epidural Hematom Acil Cerrahi \\ Durum mudur?
}

\begin{abstract}
Spontaneous spinal epidural hematoma (SSEH) is a rare condition requiring urgent diagnosis and treatment. Patients with SSEH typically present with acute onset of severe back pain and rapidly develop signs of compression of the spinal cord. The authors present a case with spontaneous resolution of SSEH which is extremely rare. We discuss a man who presented to our clinic with mild paraparesis at the seventh day of his symptoms. He had a history of poorly controlled hypertension and hypercholestrolemia requiring an antihyperlipidemic agent and anticoagulation. His upper level of hypoesthesia was at the third thoracic segment. Cervicothoracic SSEH was diagnosed by magnetic resonance imaging. Since there was a gradual recovery of the neurological deficits beginning 12 hours after the onset of symptoms, surgery was obviated and strict bed rest, serial neurological examinations, and pain controls with opiates were instituted. The neurological deficits showed complete recovery on the 25th day of the clinical course. SSEH is rare and immediate surgical decompression is suggested. Rapid neurological deterioration followed by early and progressive neurological recovery, confirmed by radiological resolution of the lesion, may indicate nonoperative treatment.
\end{abstract}

KEYWORDS: Conservative management, Spontaneous spinal hematoma, Surgery

\section{ÖZ}

Spontan spinal epidural hematomlar (SSEH) acil tanı ve tedavi gerektiren nadir durumlardır. SSEH hastaları tipik olarak şiddetli başlayan sırt ağrısı ve hızlı bir şekilde gelişen spinal kord bası bulguları gösterirler. Yazarlar çok nadir görülen SSEH'un spontan kaybolduğu bir olguyu sunmaktadırlar. Semptomlarının 7. gününde kliniğimize orta şiddette paraparezi ile başvuran erkek hasta tartışıldı. Hastanın öyküsünde antihiperlipidemi ve antikoagülan ilaç kullanımı gerektiren kontrol altında olmayan hipertansiyon ve hiperkolestrolemi mevcuttu. Duyu kaybı torakal 3 seviyesindeydi. Magnetik rezonans görüntülemede servikotorakal SSEH görüldü. Semptomların başlamasından 12 saat sonra nörolojik kusurların düzelmesi nedeni ile cerrahi ötelendi ve mutlak yatak istirahatı, sıkı nörolojik takip ve opiatlarla ağrı kontrolu sağlandı. Klinik seyrin 25 . gününde nörolojik kusurların tamamı düzeldi. SSEH nadir bir durumdur ve acil dekompresyonu önerilir. Ani nörolojik kötüleşmenin ardından erken dönemde başlayıp giderek ilerleyen nörolojik düzelme ile beraber radyolojik olarak da iyileşmenin desteklendiği durumlarda konservatif tedavi uygulanabilir.

ANAHTAR SÖZCÜKLER: Cerrahi, Konservatif tedavi, Spontan spinal hematom

\section{Sait SIRIN \\ Erhan ARSLAN \\ Soner YASAR \\ Serdar KAHRAMAN}

Gulhane Military Medical Academy, Department of Neurosurgery, Ankara, Turkey

Received : 01.09.2009

Accepted : 06.10.2009

Correspondence address:

Sait SIRIN

Phone : +90 3123045316

E-mail: drssirin@yahoo.com 


\section{INTRODUCTION}

Spontaneous spinal epidural hematoma (SSEH) causing cord compression is a neurosurgical emergency. Standard treatment is urgent operative decompression (3). The level of the lesion (e.g. cervical or thoracolumbar region) is usually localized by clinical presentation and examination. Magnetic resonance (MR) imaging is the golden examination for diagnosis of SSEH. The previous reports emphasized the importance of earlier decompression for better neurological recovery and outcome (3).

Spontaneous spinal epidural hematomas are usually associated with coagulopathy, vascular malformations, neoplasm, minor trauma, and pregnancy. We would like to illustrate the importance of this point with a case of spontaneous cervicothoracic epidural hematoma, where the patient had a complete neurological recovery from profound deficits. This case of SSEH is unique in its association with a spontaneous resolution of symptoms while in the Emergency Room (ER) and its non-surgical conservative management.

\section{CASE REPORT}

A 77-year-old man presented to his local hospital with the sudden onset of neck pain, numbness, and total weakness in the lower extremities. His complaints had started 40 minutes before admission to ER. Observations on admission included blood pressure of $210 / 100 \mathrm{mmHg}$ and a body temperature of $37.2{ }^{\circ} \mathrm{C}$. He reported that he could move his left leg minimally and had some sensation after 12 hours. Definitive imaging could not have been proceeded at this local hospital. The patient was discharged without any diagnosis and treatment. After 7 days, the patient was admitted to our department with lower extremity weakness and urinary incontinence. Upon neurological examination, there was paraparesis (muscle power scored as $4 / 5$ ) and hypoesthesia below the level of T3. There was also progressive improvement in all sensory modalities in every dermatome. Since the neck pain of the patient had not been resolved, MRI of the cervical and thoracic spine was performed (Figure 1A,B,C). The MRI revealed a fusiform mass in the dorsal spinal canal causing canal stenosis centered at T1 without spinal cord signal change. The mass had compressed the cord anteriorly and extended from the level of C6 to T3 centering at T1. The mass was peripherally hyperintense and centrally isointense on the T1W images. It had an isointense signal on the $\mathrm{T} 2 \mathrm{~W}$ images. The signal characteristics of the lesion were most consistent with a large posterior subacute epidural hematoma. The patient was admitted to our department with a plan of close observation and non-operative management. Of note, his medical history included poorly controlled hypertension and hypercholesterolemia requiring an antihyperlipidemic agent and anticoagulation (acetylsalicylic acid $100 \mathrm{mg} /$ day). Upon admission, his coagulation panel was normal with an INR 1,0 and platelet count of 370 . Strict bed rest, serial neurological examinations, and pain control with opiates were instituted. A repeat MRI done on hospital day 25 revealed the resolution of the epidural hematoma in the dorsal spinal canal (Figure 2). The patient was discharged without neurological sequelae.

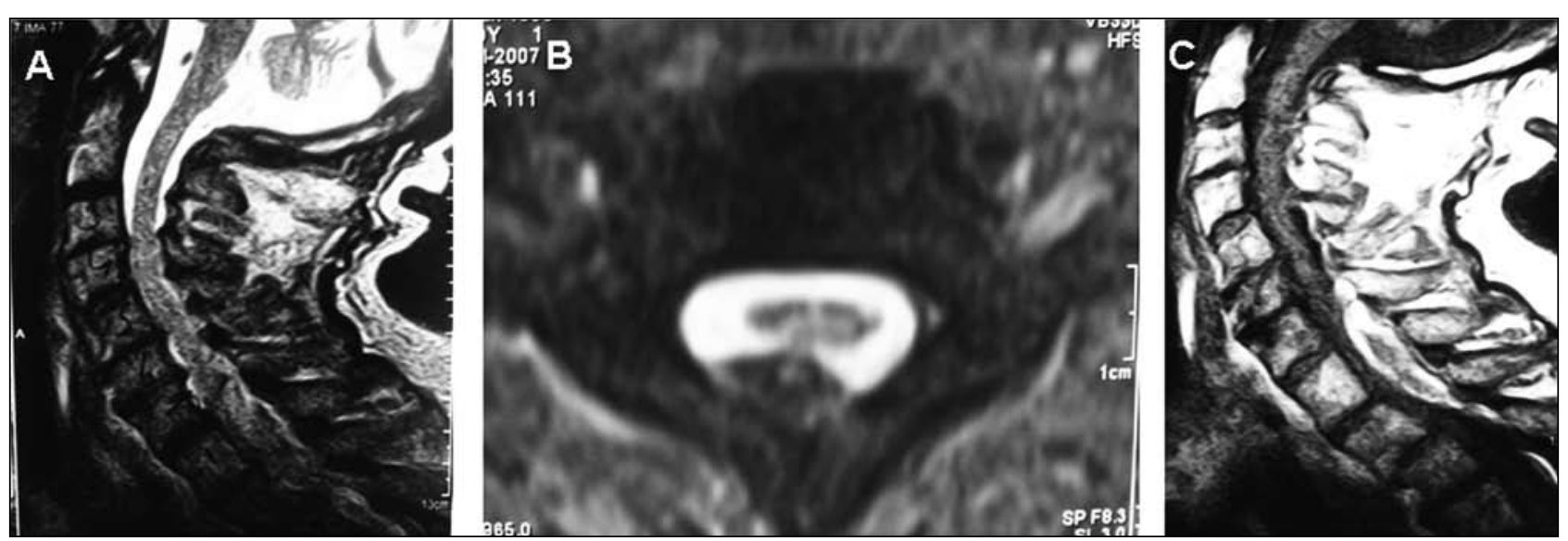

Figure 1: Initial sagittal (A) and axial (B) T2W images obtained 7 days after symptom onset reveal a long segment of epidural hematoma that is isointense in signal to spinal cord and causes severe cord compression. A concomitantly obtained T1W sagittal image $(C)$ shows an epidural hematoma that has a peripheral hyperintense and central isointense signal to spinal cord consistent with subacute epidural hematoma. 


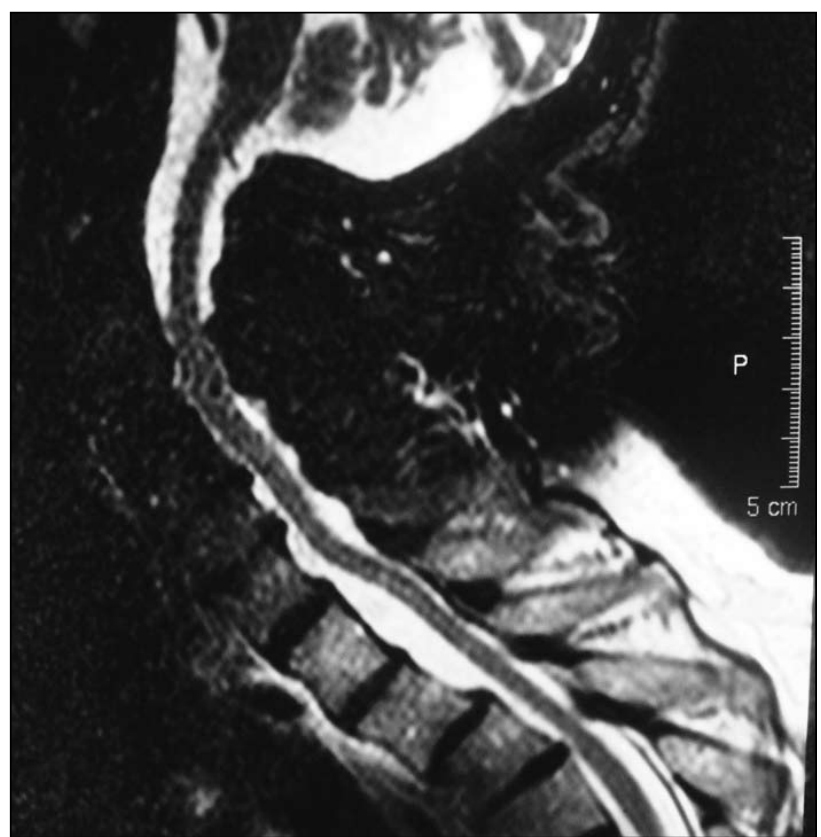

Figure 2: Follow-up sagittal T2W image, obtained 25 days after admission, shows complete resolution of the hematoma.

\section{DISCUSSION}

Spontaneous spinal epidural hematoma is a rare cause of spinal cord compression, with a frequency of less than $1 \%$ of spinal space-occupying lesions (1). Because of better diagnostics with sensitive imaging techniques such as CT and MRI, the annual incidence of SSEH estimated at 0.1 per 100,000 may be increasing (8). The male/ female ratio is $1.5: 1$, and most cases occur between the ages of 50 and 80 years (7).

Theetiology ofSSEHis unknown, but predisposing factors such as hypertension, anticoagulant therapy, increased venous pressure (straining, sneezing, lifting, or whooping cough), pregnancy or labor, and vascular malformation have been described $(4,14)$. The causative hematomas most frequently occur at the lower cervical and thoracolumbar spinal levels in adults, as in our case; they commonly affect C5 to T1 spinal levels in children (18).

Sudden onset of severe back or neck pain around the involved vertebrae with radiating pain around the corresponding dermatomes is the usual classic clinical presentations (14). Symptoms and signs of spinal cord compression such as ascending numbness, radicular paresthesia, and progressive paraparesis appear within minutes to days (1). As the epidural space is narrowest between $\mathrm{T} 3$ and $\mathrm{T} 9$, the typically short course from pain to paralysis is common in thoracic and cervical cases $(7,9)$. If left untreated, complete permanent neurological deficits or even death may be seen because of progressive spinal cord compromise (6). However, the exact pathogenesis of the spinal epidural hematomas remains still obscure (11). Based on the predominance of posterolateral hematomas with segmental distribution, the most likely source may be the posterior epidural venous plexus (8). Because of fluctuations in intrathoracic and intraabdominal pressures after exercise or other maneuvers, reversal of blood flow may induce rupture of a delicate vein in the valveless epidural plexus (18). As venous epidural pressure is less than intrathecal pressure, other researchers have considered an arterial rupture as the origin of the bleed (6).

CT myelography has been replaced by MRI as the most suitable diagnostic method for SSEH $(6,12,14)$. The majority of SSEH are located dorsally, with only a few cases were reported in the ventral side (13). T1 and T2 signals associated with SSEH vary based on clot characteristics, age, size, and oxygenation (12). Within the first 24 hours after onset of symptoms, the hematoma usually appears as an isointense signal on T1-weighted imaging and a hyperintense signal on T2-weighted imaging (14). Peripheral enhancement of the lesion is mostly found with post-contrast MRI (12). In the differential diagnosis of other diseases, such as spinal abscess, neoplasm, ischemia, transverse myelitis, and acute vertebral disc disease, these radiological findings may help distinguish SSEH (1). In our case, the mass was peripherally hyperintense and centrally isointense on the T1W images. It had an isointense signal on the $\mathrm{T} 2 \mathrm{~W}$ images. The signal characteristics of the lesion were most consistent with a large posterior subacute epidural hematoma compressing spinal cord.

Torres et al. (19) recommended early surgical evacuation for patients with spontaneous or traumatic spinal hematomas who presented with severe neurological deficits and conservative management for those with minimal neurological involvement. Patients with acute neurological deficits because of a SSEH require immediate surgical decompression; however, rare spontaneous resolution without surgical intervention has been documented, as in the presented case $(2,8,10,13,16,20)$. Surgical decompression usually involves bilateral laminectomy, or more rarely, hemilaminectomy with hematoma evacuation 
$(5,15,17,21)$. Decompression must be immediate, since death from respiratory failure has been documented $(5,21)$. If a significant amount of time has passed since the event and neurological symptoms are stable, it may be acceptable to closely monitor the patient. Our patient was admitted to our department after 7 days with progressively improving mild paraparesis and hypoesthesia. Therefore, we decided to give him pain killers and strict bed rest with serial neurological examinations. His clinical course was uneventful, with progressive complete recovery from neurological deficits. His MR images showed total resolution of SSEH.

\section{CONCLUSION}

Although SSEH is very rare, it should be considered in the differential diagnosis of sudden onset of severe upper and/or lower extremity weakness with neck pain. Rapid neurological deterioration followed by early and sustained neurological recovery, confirmed by radiological resolution of the lesion, may indicate non-operative treatment.

\section{REFERENCES}

1. Alexiadou-Rudolf C, Ernestus RI, Nanassis K, Lanfermann H, Klug N: Acute nontraumatic spinal epidural hematomas. An important differential diagnosis in spinal emergencies. Spine 23:1810-1813, 1998

2. Anderson TJ, Donaldson IM: Spontaneous resolution of cervical spinal epidural hematoma. Postgrad Med J 65: 488-490, 1989

3. Chan DT, Boet R, Poon WS, Yap F, Chan YL: Spinal shock in spontaneous cervical spinal haematoma. Acta Neurochir (Wien) 146:1161-1163, 2004

4. Chen CJ, Hsu WC: Imaging findings of spontaneous spinal epidural hematoma. J Formos Med Assoc 96:283-287, 1997

5. Demierre B, Unger PF, Bongioanni F: Sudden cervical pain: Spontaneous cervical epidural hematoma. Am J Emerg Med 9:54-56, 1991

6. Dinsmore AJ, Leonard RB, Manthey D: Spontaneous spinal epidural hematoma: A case report. J Emerg Med 28:423-426, 2005
7. Foo D, Rossier AB: Preoperative neurological status in predicting surgical outcome of spinal epidural hematomas. Surg Neurol 15:389-401, 1981

8. Groen RJ: Non-operative treatment of spontaneous spinal epidural hematomas: A review of the literature and a comparison with operative cases. Acta Neurochir (Wien) 146:103- 110, 2004

9. Groen RJ, van Alphen HA: Operative treatment of spontaneous spinal epidural hematomas: A study of the factors determining postoperative outcome. Neurosurgery 39:494- 508, 1996

10. Hentschel SJ, Woolfenden AR, Fairholm DJ: Resolution of spontaneous spinal epidural hematoma without surgery: report of two cases. Spine 26: 525-527, 2001

11. Hsieh CT, Chang CF, Lin EY, Tsai TH, Chiang YH, Ju DT: Spontaneous spinal epidural hematomas of cervical spine: Report of 4 cases and literature review. Am J Emerg Med 24:736-740, 2006

12. Jamjoom ZA: Acute spontaneous spinal epidural hematoma: The influence of magnetic resonance imaging on diagnosis and treatment. Surg Neurol 46:345-359, 1996

13. Kato S, Seki H, Koshu K: Acute cervical spinal epidural hematoma with spontaneous resolution: Case report. Neurol Med Chir (Tokyo) 34:23-26, 1994

14. Liao CC, Lee ST, Hsu WC, Chen LR, Lui TN, Lee SC: Experience in the surgical management of spontaneous spinal epidural hematoma. J Neurosurg 100:38-45, 2004

15. Lobitz B, Grate I: Acute epidural hematoma of the cervical spine: An unusual cause of neck pain. South Med J 88:580-582, 1995

16. Marinella MA, Barsan WG: Spontaneously resolving cervical epidural hematoma presenting with hemiparesis. Ann Emerg Med 27:514-517, 1996

17. Pan G, Kulkarni M, MacDougall DJ, Miner ME: Traumatic epidural hematoma of the cervical spine: Diagnosis with magnetic resonance imaging. J Neurosurg 68:798-801, 1998

18. Patel H, Boaz JC, Phillips JP, Garg BP: Spontaneous spinal epidural hematoma in children. Pediatr Neurol 19:302-307, 1998

19. Torres A, Acebes JJ, Caiol J, Gabarros A, Lopez L, Plans G, Teixidor P: Spinal epidural hematomas. Prognostic factors in a series of 22 cases and a proposal for management. Neurocirugia 15:353-359, 2004

20. Wagner S, Forsting M, Hacke W: Spontaneous resolution of a large spinal epidural hematoma: case report. Neurosurgery 38: 816-818, 1996

21. Williams JM, Allegra JR: Spontaneous cervical epidural hematoma. Ann Emerg Med 23:1368-1370, 1994 